Jan VOREL

DOI: $10.14746 /$ bo. 2020.3 .4

University of Ostrava

\section{Genesis of Czech Decadence and Symbolism Towards Theurgy}

Keywords: Czech literature at the turn of $20^{\text {th }}$ century, Decadence, Symbolism, Metamorphoses of Aesthetic-philosophical Concept of Symbolism, from Decadent-Symbolism to Theurgic Symbolism, Theurgy, Art as a Complex Way of Thinking and Understanding of the World, Synergy of Aesthetic and Religious Spheres

Klíčová slova: česká literatura přelomu 19. a 20. století, dekadence, symbolizmus, metamorfózy esteticko-filozofických koncepcí symbolizmu, od dekadence k teurgickému symbolizmu, umění jako způsob chápání světa, synergie estetické a religiózní sféry

\section{Abstract}

The article is focused mainly on metamorphoses of aesthetic-philosophical approaches of the most important representatives of Czech literature at the end of $19^{\text {th }}$ and beginning of $20^{\text {th }}$ century whose work presents gradual heading for modern art, from decadent to symbolist focus using an aesthetic theory of Russian philosopher Vladimir Solovjov based on theurgic substance of art.

The aim of this study is to show genesis of Czech literature at the end of $19^{\text {th }}$ and beginning of $20^{\text {th }}$ century. Our interest will be focused mainly on metamorphoses of aesthetic-philosophical approaches of the most important representatives whose work presents gradual heading for modern art, from decadent to symbolist focus. The interest will be aimed at metamorphoses of modern art, from decadent-symbolist one to evolutionary and at the same time high phase of symbolism, which can be called theurgic, using the words of the Russian philosopher, poet and dramatist Vladimir Solovjov (1853-1900). One of the key points of philosophical and aesthetic theory of Vladimir Solovjov is the idea of so called unitotality (Всеединство). This philosophical category covers the idea of organic unity of the universal existence of the world, in other words, such a state of existence of cosmos where all the existing works in mutual relationship, inner connection, and it creates the only vast complex. Then, in accordance with these ideas Vladimir Solovjov defines theurgy as the effect of a human on force majeure influencing the course of world events. Any creation is understood as theurgic and is associated with metaphysics and spiritual secret.

Thus, theurgic nature of artistic activity represents the possibility to transform the existence by means of aesthetic sphere:

O tom, že takový význam umění není výmysl, svědčí někdejší nerozdělitelné spojení mezi uměním a náboženstvím... Současné odcizení umění a náboženství považuji za přechodné období, kdy byl zrušen jejich ne vždy svobodný svazek, aby obě tyto tolik důležité stránky lidského bytí vykročily k budoucí syntéze. Dokonalý život, jehož předběžnost spatřujeme $\mathrm{v}$ pravém umění, bude přece také založen na vzájemném svobodném působení lidského a božského elementu a ne na otrocké závislosti na božství (Solovjev 1997, s. 124-125).

Anchoring of unitotality in the outer reality and its embodying in the framework of visible, material existence is considered as a demonstration of absolute beauty. In the very initial stage of development of modern Czech literature, art groups and writers were conditioned by sticking to the same philosophical and aesthetic bases and to European literatures where the turn to the modern art streams - that overcame the realistic-naturalistic school - had already been done.

In early-decadent-symbolist phase of development of Czech literature making effort to get over the reality by the way to spiritual visions and dreams, by negation of materialistic being is symptomatic. In decadent-symbolist aesthetics there came into existence the opposition of two worlds - the world of subjective and objective, spiritual and material, abstract and concrete, outer and inner; the worlds outer to an individual, and worlds existing only in the soul of an individual. The deepest abyss opened beneath them in modern art:

A přece nelze zapomenouti, že umělecká a životní pravda jsou dvě dosti rozdílné věci. Lze skoro říci, že tam, kde umění má pravdu, život má téměř vždy nepravdu, a že smyslu věcí nám neřekne svět reální, ale pouze náš sen. Čím větší rozpor mezi 
životem a dílem umělcovým, tím větším uměním dílo bylo vytvořeno. Jen u malých umělců se kryje život a dílo (Karásek ze Lvovic 2002, s. 7).

Thus the world of art creation had become a passionate struggle for pure artistic values, for spiritual world of human, for transcendent and metaphysical dream with its strong sense of secret of human life, found in extra-sensual sphere; for noble culture. This state of culture could be reached only through the ways of tense imagination and dreams as the essential sources of real art:

Abych se omezil na umění: pouze nejmocnější vize bytí, pouze nejintenzivnější citovost, pouze nejvášnivější vztah k životu, pronikavé oko pro jeho velikosti a propasti, jeho kořeny a tajůplné projevy dodává schopnosti tvořiti umělecké dílo. Průměrnost je čas, př́tomná chvíle, den ze dne, malost, nevýraznost a planá všednost, tisíckrát a tisíckrát se opakující, - umění věčnost, zázračná výjimka a božský osud. Umění je samo pro sebe, prostředkem a cílem zároveň. Nezná a nezamýšlí nic mimo sebe. Jeho hodnota je v jeho tvůrčí intenzitě vize a senzibility. Proto je vždy individuálním. Proto není hromadného umění. Při tom, čemu se běžně a nepřesně tak říká, jest omylem a klamem bud' adjektivum, to jest není hromadným, nebo substantivum, to jest není uměním - zaměňují se ledabyle tvưrčí schopnost a prostá zděděná nebo naučená výtvarná zručnost, krása a pouhé pěkno, umění a umělost, jako př̀ lidovém uměleckém průmyslu například. Umění samo není ovšem pro každého, pro všecku chudinu duchem. Jako produkovati je nemnohým požehnaným je dáno, také není každému uštědřeno chápati, milovati, prožívati je znova (Procházka 1913, s. 49).

At the end of $19^{\text {th }}$ century, leading representatives of Czech decadence and symbolism stood on a radical refusal of realistic-naturalistic model of art, based on creating social documents. Therefore, Arnošt Procházka (1869-1925), Jiř́ Karásek ze Lvovic (1871-1951), rejected the linking of art with democratic mass and aesthetization of issues with low importance, collectivity and banality. In opposition, aesthetization gained absolutely different connotations. Art that must not lead to satisfying of vital needs becomes for them totally autonomous world with its laws, and its constant creative force and immortality are hidden exactly in the fact that "it is life in life, world in world and cosmos in cosmos":

Miluji ted’ život i tak jak jest: jeho jako zamodralé kouzlo rozestřelo se mi nad všemi věcmi a bytostmi. A v každé kráse, kterou sním a žiji, cítím, že jsem bliže k jeho tajemství. [...] Jednoho se bojím: dne, kdy bych ztratil svou souvislost s krásou a s uměním. Vše ostatní je bez ceny. Vše ostatní klame (Karásek ze Lvovic 2001, s. 58, 61).

In their opinion, art cannot have anything in common with ethic, social and national standards and suppositions:

Snaží-li se však spisovatel úmyslně produkovati dílo sociálně užitečné a moralistní a přitom umělecké, nikdy nedospívá své mety, jeho plod je tendenční zmetek, jenž se opičí po umění, ale nikdy ne umělecké dílo... [...] Přijímati a ceniti nezištnou krásu nějakého uměleckého gesta, které nechce ničeho jiného mimo tuto krásu zrovna, jest dáno málokterým, velice vzácným, prařídkým málokterým (Karásek ze Lvovic 2001, s. 18,15$)$.

Thus, a real artist must strive for presenting the ideal of beauty and the work of art must extract everything from reality, as its most precious form which is in direct relation to artist's individuality or soul. Therefore, the character of modern art that was affected by a strong flashover of spiritualism, influences also its relationship to the real world, which is gradually becoming directly dependent on inside states of human soul:

Má-li však kdo schopnost neviděti, už tím je básníkem, i kdyby nežil pro něj vyhalucinovaný svět fikcí, ohněm a inspirací zbarvený. [...] A proto může-li mi býti po př́ipadě lhostejný ten, $\mathrm{s}$ nímž jsem se setkal v životě, nikdy mi nemůže být lhostejný někdo $\mathrm{z}$ těch, jež jsem potkal ve svém snu. [...] A vím, že jediné je pravdou: skutečnost nenáleži do umění. Třeba svou myšlenku osamostatniti od života a každé slovo vsaditi jako doprostřed velikého zlatého kruhu, by bylo oddáleno od všednosti. Daleko nad skutečnost a mimo ni musí jíti umění, a tam, kde náš sen prošel životem, musí dříve býti očištěn ode všeho, čím jej život poskvrnil, než může o něj umění se zajímati (Karásek ze Lvovic 2002, s. 8, 9).

Nevertheless, in aesthetic theories of Czech followers of decadent-symbolist aesthetics, we can see traces of efforts to overcome clearly decadent approaches to the integral understanding of the problem. However, that was extensively defined later by next art generation who started understanding art creating in its broader meaning as theurgy. Arnošt Procházka spoke about the art that reaches the farthest from the branches of human knowledge as it is gifted by deep intuition, enabling it to unveil and infer the "centres of spiritual lands, hid- 
den in reality". Creating artists find unlimited broadness of transcendent reality, of metaphysical relevance and relations to eternity and infiniteness:

[...] když básník ve svých nejvzácnějších a nejslavnějších hodinách jasnovidně byl prošel ve snu svým minulým světem, když se byl prolnul intimně jeho nejryzejší podstatou, když byl vstřebal v lačné horoucnosti jeho nejvyšší harmonii, by z ní a ze své bytosti stvořil onen zašlý okruh lidského bytí v jiném svém řádu. [...] To jediné jest umělecky tvưrčí nazírání a poznání... [...] .... tento člověk tvoří harmonický celek se svým okolím, je postaven v místo, které s ním splývá v jednotu... (Procházka 1912, s. 62,72 )

Also, Jiř́ Karásek ze Lvovic applied identical approach. He was convinced that by means of words-symbols it is possible to transcend reality and view it in its purest spiritual form, in out-of-time empire of ideas, which can enable connecting of "present moment with fluent line of eternity". Thus, the modern artists change into thinkers whose work becomes an absolute aesthetization of an idea; they can fix the purest ideas and synthesize everything in "the only one, essential, original":

Myslím tím básnickou schopnost, promítati nitro své $\mathrm{v}$ tok chvíle, všechno věčné $\mathrm{v}$ duši $\mathrm{v}$ tok př́tomnosti, všechno nebeské $v$ nitru $\mathrm{v}$ tok pozemskosti a vyslovovat obrazy a symboly pozemskými to, co je v duši věčné, lidsky věčné. [...] ...dýcháte už někde jinde, ne sice někde v nadzemském světě, ale přece jen na výšinách, kde je čistš vzduch (Karásek ze Lvovic 1927, s. 93, 164).

These shifts are probably the most noticeable in decadent-symbolist aesthetics of authors who were associated with Moderní revue magazine, they can be traced in essayistic and art work of Miloš Marten (1883-1917). Particularly in his aesthetic approaches, we can search and find new ways to the symbolism, seen as the art that creates the organic creative order and that integrates our comprehension and learning about the world. Miloš Marten strives for a new synthesis when art, going beyond the reality, broadens the understanding of the sense of world and existence. For Marten, art is emanation of "unified power" that is the essence of life itself":

A tyto nové prvky, tuto novou duchovou realitu uvésti ve vztahy stejného původu, aby tvořily zvětšený geometrický obraz života a budily dojem jeho průmětu do duchových sfér - v tom je hlavní moment estetické hodnoty. Tu člení se kritérion života ve dvě podrobné, speciální otázky o typu uměleckého díla. První po individualitě umělcově, jejích psychických vlastnostech a možnostech: otázka, jak realita (zkušenost vnitřní i vnější) se odrazila v duchovou sféru umělcovu a jak se lomem světla při přechodu z prostředí do prostředí její reliéf změnil; po zvláštnosti umělcova vnitřního ustrojení, jeho bytosti citové a intelektuální. Druhá zkoumá způsob a rytmus fiktivního světa, jenž onou transformací povstal; zní, jaké zákony vztahu umělec vložil do vzájemných styků a reakcí bytostí a tvarů, které stvořil. Otázka pravdivosti a prožitosti uměleckého díla jest tím zavinutě položena. Jako nelze myslit prožitostí faktické zažití v realitě, nýbrž jen intenzívní zúčastnění umělcova jáství na féerických dobrodružstvích jeho fiktivního světa, stejně pravdivost neznačí shodu vidiny s realitou, ale zákonitost jejího složení a rozvinu - měřítko dá pocit síly, rytmicky činné, a dojem koordinace, souvislosti, príčinnosti (Marten 1995, 312).

The beginning of $20^{\text {th }}$ century brought changes in symbolistic aesthetics. At the turn of the century, representatives of this literary movement crave to overcome individualistic separation and aesthetic subjectivism of decadent-symbolistic aesthetics shortly after its origination. From the aesthetic-individualistic viewpoint, symbolism shifted the subjective-individualistic understanding of the world to the objectivistic-idealistic concepts. Symbolic artists started to understand the meaning of art as a transcendent reality and their creative method was determined by dualism which put the world of ideas and the real world in opposition.

For symbolist artists, objects of the phenomenal world became "images of ideas". In each unique real phenomenon, "a higher sense" is seen and searched for; which means that each artist was aiming at seeing and recognizing the abstract in an individual phenomenon whose individuality and uniqueness was thus kept and strengthened by being presented in bonds with the higher unity.

An elementary unit of symbolism is the symbolization as a process of cognition of the eternal and the sacred in the profane world, and a method of presenting ideas in images. The symbolist image tended to its transformation into "image-sign", hiding a mystic idea in itself and it was understood as a complex unity of spiritual essence and material existence. 
Literature of this period also gave birth to the concepts of "new synthesis", and "theurgic essence of art". Synthesis and theurgy were understood in religious and mystic way, and they targeted gradual transformation of world and life.

Russian philosopher, V. Solovjov defines the idea of synthesis by means of the difference between the ideal (valuable) and ill-suited, worthless existence. The difference is determined by the mutual relationships among the parts of a certain complex and their relationships towards the complex itself. A full-fledged idea and beauty are directly specified as a freedom of constitutive parts in the perfect unity of the complex:

Za prvé: když se dílčí elementy vzájemně nevylučují, ale naopak, vzájemně vytvářejí celek, panuje mezi nimi solidarita. Za druhé: když nevylučují celek, ale své dílčí bytí potvrzují na jednom všeobecném základu. A nakonec za třetí: když nejediný základ čili absolutní princip nepohlcuje a neničí dílčí elementy, ale odkrývá jim $\mathrm{v}$ sobě plný prostor - tehdy, $\mathrm{v}$ těchto třech př́padech, lze mluvit o ideálním čili hodnotném bytí, tj. o takovém, jaké má být. [...] Lží nazýváme myšlenku, která vyzdvihuje výlučně jednu z dílčích stránek bytí, a tak popírá ostatní. [...] Ošklivost se vyskytuje všude tam, kde se jedna $z$ částí př́liš rozrůstá a převládá nad jinými. Ošklivé je to, co není jednotné a celistvé, anebo naopak to, co není svobodně různorodé (Solovjev 1997, s. 118-120)

The ways of synthetic and theurgic art went beyond the borders of traditional understanding of art creation and its followers often defended their aesthetic-philosophical concepts by the fact that in their creative efforts they are returning to the roots and tasks of art. The common factor of concepts of symbolist art was understanding of wordsymbol, which in standard terms and every-day-use words, was able to reveal hidden magic meaning and energy. They were used as a means of communication between the two worlds (the profane and the sacred), and gave them "higher creative power", being able to change the nature of the material world. Naturally, this word magic reflected itself in the character of all art works of this evolutional stage of symbolism; thus, on the grounds of mystic-religious art work, a mystery was re-born, during which magic influences the form of microcosm and macrocosm.
The particular term of theurgy ("free theurgy", "the whole creation") as a category of aesthetic of so called Early Symbolism was understood by the Russian philosopher V. Solovjov as a substantial unity of art creation influenced by mystics and religion whose essence lies in communication of material world and the world of ideas by means of "core exposition of creative act" based on an organic unity of the ideal side and its material side. Thus, there was forwarded the conviction that art was to enter a free connection with religion; subsequently the term of religious sense of art started being used. Through the prism of this aesthetic-philosophical system, the contemporary culture was viewed as a tragic epoch in the evolution; therefore, theurgic concepts were assigned to overcome that state and create organic metaculture as the final stage in evolution of human civilization.

The essence of the theurgic art requires the aesthetic beautiness to influence the reality positively, so that it is capable of controlling and deepening the reality. To put beautines in work, we need mutual penetration of two creative elements: materialization of spiritual essence and complete spiritualization:

1) přímá objektivace nejhlubších vnitřních určení a vlastností živoucí ideje, které příroda nedokázala vyjádřit, 2) zduchovnění prrírodní krásy a skrze to - 3) zvěčnění jejich individuálních jevů (Solovjev 1997, s. 124).

Presence of this spiritual fullness, in our reality, metamorphosis of our life to absolute beauty and creation of cosmic spiritual organism is finally the highest goal of art of future:

Umění je proto přechodným a pojícím článkem mezi krásou přírody a krásou budoucího života. Takto chápané umění už není prázdnou hrou, ale stává se důležitou a poučnou záležitostí, ovšem nikoliv v kantorském smyslu, ale ve smyslu inspirativního PROROCTVÍ. [...] Umělecké ztvárnění je každé znatelné zobrazení předmětu nebo jevu z pohledu jeho definitivního stavu nebo ve světle budoucího života (Solovjev 1997, s. 124).

In this sense, the followers of theurgic art stand against anti-traditionalism and aesthetic separatism of the preceding literary generation proclaiming the idea of pure art, more or less intensively: 
Zdá se divné uvěřit v krásu jako v záruku spásy světa, když musíme zachraňovat samotnou krásu před kritiky, kteří chtějí z ideálního krásna udělat reálnou ohavnost. Budeme-li povzneseni nad všechny hrubosti současného estetického realismu (a utilitarismu), můžeme jej hlouběji studovat. Najdeme v něm řadu nesmyslů a protiřečení. Nelze však opomenout, že současný trend také uznává nejcennější celosvětový význam krásy. Tím její zdánliví pronásledovatelé vlastně obhajují náš názor, že krása spasí svět. Čisté umění čili umění pro umění je zavrhováno jako jalová kratochvíle. Ideální krásou se opovrhuje, protože je považována za prázdnou a nedůležitou okrasu skutečnosti. Z toho vyplývá, že kritika požaduje, aby současné umění bylo důležitou záležitostí, to znamená, aby jako pravá krása hluboce a silně působilo na reálný svět (Solovjev 1997, s. 57).

Followers of early symbolist generation perceive the beautiness as life fullness and striving for life penetrating all nature, concurrently as striving for creation of the beautiness. Art became the way of bringing about the worldwide unity, idea of organic life, when all the earth and spiritually united humankind head for the yet invisible but powerful spiritual centre and complex existence (see for example the symbols associated with Western and Eastern civilization, symbols of maturing and growth, building temples, symbols of connection of brothers).

Even the field of poetics noticed changes, where we can see deepening of the abyss between poetic language and the principles of logical thinking. Conceptual thinking is applicable only in connection with intellectual cognition of outer world and cognition of higher reality may be merely mediated by intuition and by means of symbolist images. Art works created by followers of this concept transformed into mysteries where symbolism of colours and composition processes associated with other types of art, for which the rational, conceptual thinking is absolutely unfamiliar (especially music), play an important role. Gradually, merger of poetry and prose was becoming stronger in literary art. Some of genial creative experiments, synthetizing art processes typical for music, literature and fine art were launched. They resulted for example in poetic essays, mystery plays, experimental prose based on application of composition principles of musical symphony in connection with anthroposophic ideas of streaming of world energies and "metaphysic of colour and sounds".
Art work and essayistic work of writers as mentioned bellow are connected by the idea of art which possesses mystic power, the idea of "all-human" art together with cognitive act. Art is perceived mostly as a complex system of thinking and understanding of the world (modus cogitandi) and the way of existence there (modus vivendi). As the most important thing, it was operated with finding of new perceptive ways and expressing and reaching the state of existence when the artistic images would not only evoke the impression of beauty but, at the same time they would work as the means of cognition. Thus, for people, they would develop the capability to see the "theurgic sense" of demonstrations of life.

As a first we focus on Julius Zeyer (1841-1901), who is traditionally linked to Lumír generation (cosmopolitan stream of Czech literature of $19^{\text {th }}$ century). However, epic art work of Julius Zeyer is significant for cognitive efforts towards creative essence of the world; the author himself called it a "renewed image", which can be generally in simple way described as free inspiring by the ancient mythical, legendary historical and also literary themes of different epochs, nations and cultures. Vast majority of his art work is made by the themes adopted from the pagan and gothic times whose key feature is, as he mentions, fervent religiosity and prevalence of spiritualism over material nature of life. For Zeyer, especially the gothics became the epoch where tending for the ideal was expressed by a synthetic image of temple building. Zeyer understands that as demonstration of "higher humanity" and symbol of spiritual perspective of the world as re-connection of the material and the spiritual dimensions of human existence. Later also Otokara Březina followed and significantly developed the idea:

Ve starověku bylo umění proto tak velké, že lidé ještě bezprostředně silně po lidsku cítiti dovedli, a v křest'anském středověku bylo tak produševnělé, protože pluli lidé po bezedném moři mystiky s tak silnou vírou (Zeyer 1901-1906, s. 121).

Zeyer's art concept has also its deep meaning, which makes his art to be a certain prologue for Czech literary symbolism. In the framework of "renewed image" we speak about evocation of ancient myths, updating of stories well-known from world literatures, from general 
thematic tradition, from folk myths or oriental oral tradition. However, Zeyer does not narrate with clearly epic distance, everything is accompanied by personal reflections, echoes of his feelings and experiences, and direct participation in the story. That is the way the lyrical component penetrates into genuine epic base which the adopted theme brings along; it is an effort to create a whole image of world in the consciousness of a human.

Jan Voborník in his book called Julius Zeyer (Voborník 1908) noticed three penetrating layers, or three types of imagery in Zeyer's work of art which are represented by a direct reflection of reality, the world of philosophical idea and mythic images, and finally by the world of author's core visions. These types of imagery make a complex picture of the world, which is relevant for idea of a symbol or process of symbolization. Striving for integrity is one of the most important components of Zeyer's creative concept where in poet's "awake dreaming" (as it is the dream, which is a symbol of poetry and beauty and their relation to the transcendent for him) penetrate miscellaneous sources, to be finally merged in one giant archetypal creative stream. In the preface to Karolinská epopej (1896), Zeyer explains the essence of his creative concept. Although he perceives the contemporary art as weak and incapable of reflection of life in full, he can see one positive thing in it, which can lead to its renewal and saving. That is growing interest in values brought by ancient cultures and efforts to transfer these values in current times, and create a transcultural synthesis, whole image of human civilization, which would be easy to understand. For him, the essence of art is its ability to tend to universality and "renewal of ancient beauty", which can bring the state of integration of the spiritual and material worlds in the soul of a modern human:

[...] člověk, třeba by se zdál sobě neb jinému jinak než vpravdě je, zůstane přece jen tím, čím je, a ne tím, čím se zdál, a mimoděk, nevědomě se prozradí a ukáže ve svém jednání, ve svém smýšlení, ve svém díle v pravé podobě (Zeyer 1905, s. 20).

Věda a literatura, umění vůbec, ba i politika a sociální naše hnutí - to vše je v stadiu pouhé analysy. Boje národnostní, spory sociální, skepse v náboženství, natu- ralism v umění, empirism ve vědě: tot' sama analysa. Velikost je však jedině v synthesi, která následuje po analysi. Jsou duchové ve všech jmenovaných oborech, kteří nad svou dobou stojí, ač nedosáhli nikde vrcholku, tam dospěje svět snad za nějaké století - pyšný ten strom někdy vyroste, dnes pouze klíčí (Zeyer 1905, s. 20).

Jiř́ Karásek ze Lvovic wrote about Zeyer's work of art the following:

Zeyer sám cítil, že př́liš artistní aristokracismus jej činí nepř́stupným. Řekl to v povídce ze života Michelangelova Sníh ve Florencii ústy básníka Poliziana: Výsost znamená osaméní, velikost znamená nenávist. Vše odpustí ti dav-jen to ne, že nad nim stojí̌s, že se mu vymykáš. Ta výlučnost ti bude trnem v životě. Orfeus nesnižil se k bakchantkám, a proto jej rozsápaly. Když se potkávala dramata jeho na jevišti $\mathrm{s}$ neúspěchem, Zeyer psal je dále, $\mathrm{v}$ stejném směru, bez koncesí, věda, že by bylo podlostí proto mlčeti, že nemũže na aklamaci davu počitati (úvod k básni Kronika o svatém Brandanu). Nebot' žizníme po ideálu a ne po potlesku.. Nechce se každému do letu v modré mlhy a duhová oblaka, do kterých bych prý rád zavlekl ty, jež mi naslouchaji. Nuž, dobře, at' za mnou neletí ti, kteři nemohou, ti, kteř́ nechtěji, mně se po nich tak málo stýská, jako jim po mně... (Karásek ze Lvovic 1926, s. 110-111).

In direct connection with the concepts mentioned above, the theur$g y$ was introduced by Otokar Březina $(1868-1929)^{1}-$ i.e. synergy of aesthetic and religious spheres as conviction that artistic creation can participate in re-forming of the world:

Působiti vůlí na vůli, a tím na vytvoření reality je vlastním účelem duchové práce. Poslání umělecké v nejvyšším svém vzletu je posláním náboženským. Ale náboženským ve smyslu, jaký tomu slovu dá jednou budoucnost (Březina 2004, s. 581-582).

Otokar Březina, reached the conclusions speaking about the metamorphosis of art into an activity understood as creative unveiling and re-shaping of basic life forms, by means of aesthetic forms and deepened aesthetic principals:

${ }^{1}$ We can find the evidence about Březina's knowledge of philosophical system of V. S. Solovjov in his correspondence with E. Chalupný $\left(9^{\text {th }}\right.$ June. 1916 and $9^{\text {th }}$ April 1921), where he expressed his opinion that Solovjov's philosophical works are essential for studying contemporary philosophy and he speaks about Solovjov as follows: „[...] génius a nejhlubší myslitel ruský, filozof obdařený jasnovideckou moudrostí spravedlivou a laskavou ke všem projevủm života" (Březina 2004, s. 1316). 
Z té příčiny umění, to jest schopnost nejjemnější řečí, přistupné v tomto vtělení, čím dál více poutá člověka poznávajícího a hledajícího života. Kdo studoval dnešní okultism a zjevy vyššího psychického života, pozná brzy, že doposud na zemi dosažené vidění obou světů dálo se od géniů uměleckých, kteři byli a jsou jedinými syntetickými duchy na zemi a přetrvávají odborné učence, zakladatele věr, přesné myslitele, tvůrce systémů... (Březina 1996, s. 193).

Thus, the idea of spiritual, psychical, physiological and physical re-forming of contemporary human who would become the first step on the way to the "Solovjovian godmanhood" became the target and essence of theurgy. Then the art for Březina could head for correlation of earthly dimensions with the cosmic ones. The poets as the artists of life would reveal the hidden beauty of the world, they were led by the beauty and imagination that could set free and unite everything around in the deep intuition of spiritual essence:

Z tisíciletí do tisíciletí bloudí náš sen a nenalézá utišení, dokud se nezastavil oslněn viděním nové země pod hvězdami nového kosmu, jak ji tušíme ve svém srdci, země, kde veškeré věci nalezly své pravé místo, člověk svou pravdu, hierarchie duchů své ztělesnění v novém řádu světa viditelného, s rozkoší jako mateřství přijímána je bolest a dílem lásky stává se práce; a kde člověk, gigantské vědomí polyfonní a harmonické, pracovati bude v míru o svém posledním díle vyššími silami kosmu. [...] Tak celý svět kolem nás po tisíciletí svou krásou dává nám znamení o světě sjednocení a pokoje, po němž prahnou srdce (Březina 1996, s. 153-155).

Aesthetic-philosophical concepts of Březina took the grounds on the conviction that art was made to understand the "secret spiritual value" of phenomenal world and understand the immediate anchoring of human in the Absolute which is the resource of spiritual energy:

[...] všechny formy lidského úsilí, věda, politika, hmotná práce, náboženství, veškeré dílo vášně i snu, duchovní kázně a vzdoru, dílo jasného, po ostré disociaci pojmů toužícího intelektu i podvědomých, člověkem dosud nezvládnutých sil, všechno, co vytvořilo minulost a připravuje budoucnost, souvisí vzájemně tisíci vztahy a v hloubce, kam myšlenka se blíží s chvěním, vyjadřuje jedno duchové gesto... (Březina 2004, s. 804)

In this frame the symbolists addressed connection of principals that formed western and eastern civilization in a harmonic complex.
We can speak about new reconciliation of intuition of spiritual cosmos, deep understanding for illusive essence of things with clear and powerful activity, reconciliation of science and religion, freedom and order, sacredness and beauty which is the only aim of all arts and sciences. O. Březina was considering that point the most intensively of all. He strove for overcoming of the two extreme demonstrations of human psychical life that isolate people from real complex consciousness. He defined both the extremes as: 1) the extreme of inner ("brain", rational) life of an individual 2) life of subconscious physicality:

Národům na západě není pomoci; vždy dále bude pokračovat žízeň jejich tvorby, porostou města, hutě, laboratoře, dílny, nebot' je nutné, aby se lidstvo přesvědčilo, že na této cestě, kde zvýšená činnost rodí zvýšenou žízeň moci, rozkoše, vlády, že na této cestě není štěstí. A jako v minulých dobách, zdá se, že skrytá sídla hlubokého života jsou v srdcích žen, věrííích a milujících a v srdcích dětí (Březina 1996, s. 169).

To make it short, the art creation should head for creative connection of rationalism and contemplation in a harmonic complex which forms higher entity symbolizing perfect complexity and fullness.

As the followers of modern psychology, also Březina pondered over the problems of human consciousness. As a rule, the art must originate from the same depths where the understanding of secret of all things is realized. Therefore, equally to S. Freud and C. G. Jung, they were convinced about the existence of collective psychological crucial base, collective resource, human spiritual being which leads to understanding of life as a complex and spiritual powers hidden there; these powers are needed for transformation and resurrection of human and humankind as whole that remains unchanged and independent on the time and space; we can discover and understand there "secret initiation of life" itself:

Z duší vzdálených od sebe celá staletí a tisíciletí zavzněla v těchto chvílích slova doplňující se navzájem $v$ jediný text, jehož rozluštění bude zároveň ukončením, až se naplní věky. [...] Vstal myslitel procitlý $\mathrm{z}$ těžkého snu ležícího na myšlenkách a věcech, a jitro nové pravdy plápolalo před ním do výše v éterných, vonných plamenech... (Březina 1996, s. 19). 
Celkové vědomí lidstva jest síla, které žádný génius však nedosáhl; je nepopiratelné, že tato síla vzrůstá a že jednou bude silnější nežli síla větrů, moří, proudů elektrických, probíhajících zemí... (Březina 1996, s. 189).

Last but not least, all these aesthetic-philosophical concepts were projected in the sphere of artistic idiom. This fact as we mention above, became the focus of many aesthetic-philosophical essays of O. Březina. The way to renewal of culture was focusing on the phenomenon of word representing the base of life unity. The important issue was to give the words back their esoteric meaning and to create a word as a symbol going beyond its borders. They all saw the symbol as interaction of its three components forming a symbolic image of the observed reality as a living complex in the mind: 1) symbol as an image of visible reality calling out a certain emotion in our mind, 2) symbol as an allegory expressing ideological meaning of the image (philosophical, spiritual, and social meaning) and 3) symbol as an appeal to the creation of real life:

Každé slovo, které padlo až do živých hlubin našeho nitra (a často léta trvá tento pád), nutně, zákonem pravěkým jako početí světů, zápasí, aby se stalo tělem. Ale cesta od nového snu $\mathrm{k}$ proměně jeho v gesto a v obětování života je těžká a bolestná.. (Březina 1996, s. 80).

The real symbolist art is based on reading and understanding the words, images and symbols so that it could overreach the antinomy of "cosmic reality" and "seemingly real world". The necessary matter was to understand the essence of words as a unity of sound, existence and bearer of sense. The word-symbol enabled estimation of hidden powers of universe, recognition of the richness of the world, vision of the most minor event as a "gesture of eternity" and discovery of "the secret of spiritual progress and unity". Thanks to that the art entered new relationships with universe and the art imagery became one of means of cognition.

\section{Bibliography}

B ř e z i n a O., 2004, Korespondence I, 1884-1908. Brno: Host. B ř e z i n a O., 2004, Korespondence II, 1909-1929. Brno: Host.
B ř z z in a O., 1996, Eseje. Olomouc: Votobia.

Karásek ze Lvovi c J., 1926, Renaissanční touhy v umění. Kritické studie. Praha: Aventinum.

K a rá s e k ze L vo vi c J, 1927, Tvưrcové a epigoni. Kritické studie. Praha: Aventinum.

Karásek ze Lvovi c J., 2001, Milý príteli (Listy Edvardu Klasovi). Praha: Thyrsus.

K arás e k ze L vovi c J., 2002, Sodoma. Praha: MF.

M a r te n M., 1916, Akkord: Mácha-Zeyer-Březina: Essaie. Praha: B. Kočí, 1916.

Marten M., 1995, Kritérion života. In Moderní revue 1894-1925. Usp. Otto M. Urban a Luboš Merhaut. Praha: Torst.

M a r t e n M., 1983, Imprese a řád. Vybral, k vydání připravil, vysvětlivky, ediční poznámku a doslov napsal Emanuel Macek. Praha: Odeon.

Merhaut L., 1994, Cesty stylizace: (stylizace, „okraj“ a mystifikace v české literature přelomu devatenáctého a dvacátého století). Praha: Ústav pro českou literaturu Akademie věd České republiky.

P a p o u š e k V. a kol., 2010, Dějiny nové moderny: česká literatura v letech 1905-1923. Praha: Academia.

Pro chá zk a A., 1913, Polemiky. Praha: Kamilla Neumannová

Pro chá zk a A, 1912,. Meditace. Praha: Kamilla Neumannová.

Pynsent R. B., 1973, Julius Zeyer: The Path to Decadence. Paris: Mouton, The Hague.

S o 1 o v j e v V., 1997, Idea nadčlověka. Přel. A. Černohous. Olomouc: Votobia.

TEXTY, SNY OBRAZY, sborník zeyerovských přednášek, 1997, Usp. T. Vlček. Písek: Městské muzeum ve Vodňanech a Společnost Julia Zeyera.

V o b o r n ík J., 1908, Julius Zeyer. Spisy J. Zeyera. Praha: Česká grafická unie .

V o j t ě c h D., 2008, Vášeň a ideál. Na křižovatkách moderny. Praha: Academia.

V o j v o dí k J., 2004, Od estetismu k eschatonu: modely světa a existence v lyrickém díle Otokara Březiny: rekonstrukce symbolických paradigmat. Praha: Academia.

V o r e 1 J., 2012, Od dekadence k teurgii: (esteticko-filozofická hledání české a ruské literatury prélomu 19. a 20. století). Ostrava: FF OU.

W i e n d 1 J., 2007, Vizionáři a vyznavači. Kotázce sepětí ŕádu uměni a života v české poezii prvni poloviny 20. století. Praha: Dauphin.

Z e y e r J., 1901-1906, Spisy Julia Zeyera XXXIV. Praha: Česká grafická unie. Z e y e r J., 1905, Karolinská epopeja I. Spisy XIV. Praha: Česká grafická unie. 